\title{
Quality Cost Management in Moroccan Industrial Companies: Empirical Study
}

\author{
Lamiaa Ayach (D), Abdellah Anouar (D), Miloud Bouzziri iD \\ Faculty of Sciences and Techniques, University Hassan 1 (Morocco) \\ l.ayach@ubp.ac.ma,ab_anouar@yahoo.fr,m.bourziri04@gmail.com
}

Received: October 2018

Accepted: December 2018

\begin{abstract}
:
Purpose: The purpose of this study is to give an insight into the practices of Moroccan industrial companies in the area of managing quality costs. Furthermore, it analyses how the quality costing system (QCS) implementation and sophistication differentiate according to a number of variables (size, business market orientation, QMS Maturity...).
\end{abstract}

Design/methodology/approach: In order to achieve this objective, a questionnaire survey has been conducted among a heterogeneous sample of 1000 industrial companies that are operating in the national territory yielding a response rate of $23.4 \%$. This study uses exploratory and chi-square test in the process of answering the above-mentioned questions.

Findings: The survey highlighted the limited use of quality costing practices among Moroccan industrial companies. Results indicated that $42.6 \%$ of surveyed companies are engaged in QCS while $63.4 \%$ of them do not. The primary barrier is the complexity of QCS implementation. Besides, findings pointed out that origin, business activity, business market orientation and QMS maturity level are prominent to QCS implementation $(p<0.05)$.

Originality/value: This is one of the first studies to provide an insight into practices of Moroccan industrial companies in the area of managing quality costs. Indeed, several studies were led in different countries but no empirical study has been conducted in Morocco. This will give a clear picture of the situation at the national level.

Research limitations/implications: The major limitation of the study is the limited number of respondents. Future researches should be conducted to cover a bigger sample size from manufacturing and services sector as well.

Practical implications: The findings provide an insight into the barriers to QCS implementation which can be used as basis to identify ways to overcome these difficulties, to develop guideline and reveal best practices in the implementation of COQ reporting system.

Keywords: quality cost, quality costing system, QMS maturity level, sales revenue

\section{To cite this article:}

Ayach, L., Anouar, A., \& Bouzziri, M. (2019). Quality cost management in Moroccan industrial companies: Empirical study. Journal of Industrial Engineering and Management, 12(1), 97-114. https://doi.org/10.3926/jiem.2749 


\section{Introduction}

In a highly competitive environment, the biggest challenge for enterprises is to offer higher quality products at the lowest prices. In order to ensure this, it is required for companies to analyse and rationalise all components of their business cost. Since Cost of Quality ( $\mathrm{CoQ})$ constitutes a significant portion of the business cost and a considerable part of the sales revenue. It becomes an imperative for firms to manage and monitor quality-related costs (QRC).

Indeed, many authors (Superville \& Gupta, 2001; Uyar, 2008; Tye, Halim \& Ramayah, 2011) state that CoQ can reach up to percentages that are higher than $10 \%$ of sales revenue. However, most of companies are unaware of the quantum of their quality cost and therefore underestimate it. Quality managers use indicators for monitoring process performance and production quality, but they usually do not develop a separate framework for measuring and evaluating quality costs (Satanova, Zavadsky, Sedliacikova, Potkany, Zavadska \& Holikova, 2014).

The authors of quality cost surveys conducted worldwide reported disappointment at the small number of companies with formal system of identification, measurement and management of quality cost. They stated that only some firms implement a COQ measurement system but do not report these costs systematically, nor do they use reports properly as an opportunity for improvement (Glogovac \& Filipovic, 2017). Thus, it can be concluded that despite the recognised importance of the implementation of a quality costing system (QCS), the concept is not widely applied.

While it is unknown whether Moroccan industrial companies are engaged or not in the management of quality-related costs, it was required to perform an empirical study which highlights and presents an analysis of the situation at the national level. In this sense, the present work aims to bring out an insight into the Moroccan industrial companies practices in the area of $\mathrm{CoQ}$ management and specifically to investigate the following points:

- Identifying the level of applicability of quality cost control in Moroccan industrial companies;

- Analysing the practices of Moroccan industries in the area of managing their quality costs. Otherwise, understanding the barriers to the implementation of a QCS;

- Analysing the correlation between the characteristics of an organisation and the implementation/sophistication of a QCS;

As a research objective, industrial companies were the target. There are approximately 65505 industrial enterprises in Morocco (http://www.baromettre.directinfo.ma/) that contribute to the gross domestic product (GDP) with an average of $29.1 \%$ and offer about $21 \%$ of work places (www.cia.gov /CIA-The world factbook). Sure thing, the industrial sector plays a crucial role for economic development and job creation. Recently, Morocco is investing and banking on the development of this sector. For this reason, the survey was conducted among industrial companies with the intent to extent it later into services enterprises.

The remainder of the paper is structured as follows: the next section deals with the quality costing management and its importance to the management and performance of organisations. It also describes the previous surveys conducted worldwide. The third section focuses on research approach: The sample design, the questionnaire design and the survey procedure. Section 4 presents the results of the survey conducted within Moroccan industrial firms. Finally, Section 5 discusses the results and presents the main conclusions.

\section{Theoretical Framework}

\subsection{Quality Cost}

Quality has been long recognized as an important aspect in the decision-making of the consumers when a variety of products are available in the market. However, it is not only high quality which customers require, it is high quality with low price which attracts them and ultimately enable companies to outshine the competition (Chopra \& Singh, 2015).

Thus, to survive and compete in the market organization must reassess their production system and explore new ways of delivering higher quality products/services at an optimum cost. 
Indeed, the cost of producing higher quality may seem to carry a higher cost but this is proved false while higher quality enables companies to reduce errors, reworks, warranty charges and leads to a better use of time and materials which has a major effect on costs. Improving quality and reducing cost are thus complimentary and we can conclude that higher quality costs less.

"Diving up quality while driving down the cost" can be achieved when an organization is able to priorities its improvement activities which requires the quantification and analyze of quality relates costs. Without the guidance of QRC information, efforts to improve quality may be misdirected (Morse, 1993). COQ reporting enables identification of potential areas for improvements, which will lead to effective quality programs and eventually improve overall organizational performance.

Literature proposes a set of definitions for the concept of quality cost. Despite this, there seems to be a common idea that quality cost is a technique used to measure the performance of a quality system in order to point out its strengths and weaknesses. It is a monetary indicator that expresses the effort undertaken by a firm to ensure the intended level of quality and provide guidance on areas that need to be improved.

Generally, the cost of quality (CoQ) is defined as the expenditures associated to quality-related efforts and deficiencies. In other words, the cost related to preventing, finding and correcting defective work. Juran (1951) and Feigenbaum (1956) who first introduced the concept classified the CoQ into 4 main categories:

- Prevention cost. The cost of all activities undertaken across a supply chain to achieve good quality. i.e., the cost invested to ensure that quality requirements will be met.

- Appraisal cost: The cost off all activities undertaken across a supply chain to maintain good quality. i.e., the cost invested to evaluate that quality requirements are met.

- Internal failure cost: The losses arising as a result of poor quality detected before it reaches the customer. i.e., the costs of scrap, corrections, rework,

- External failure cost: The losses arising from a poor quality after the delivery of the product to the customer i.e. costs in relation to returns, complaints, warranty claims, etc.

The PAF (Prevention Appraisal Failure) model suggest that the investment or the increase in prevention and appraisal costs would lead to the decrease in failure costs. It is supported that nonconformance costs (internal and external failure costs) can only be reduced by enhancing expenditures on conformance activities.

Besides the PAF model which is the most known and used one, many other models were developed. Schiffauerova and Thomson (2006) classify quality cost models into four groups of generic models. There are the P-A-F (prevention-appraisal-failure) or Crosby's model, opportunity cost models, process cost models, and activity-based costing (ABC) models.

Plunkett and Dale (1987) believe that quality cost categories are dependent on the structure, technology and size of the company. Thus, organizations should select the model that suit their situation or devise their own categorization of quality cost.

Actually, the review of literature shows that COQ reporting has the potential of bringing numerous benefits such as:

- Converting quality into a measurable concept;

- Raising of awareness of the effect of poor quality upon overall business results;

- Providing room for quality improvement and guidelines to Total Quality Management (TQM) program implementation;

- Decreasing failures cost and the total quality cost;

- Helping steer and justify investments in prevention activities that lowers the total quality cost;

- Providing a new channel for communication inside the organization. 
Despite the recognized importance of the implementation of quality cost practices the concept is not widely applied. Many companies do not have formal systems of management of QRC, and are unable to take the opportunities for improvement that may result from its implementation (Ramos-Pires, Novas, Saraiva \& Coelho, 2015).

As stated in the literature, the most frequent reasons to the non-adoption of a QCS are:

- Lack of cooperation from top management

- Management unawareness of the concept of quality costing or of its benefits

- Lack of knowledge on how to identify and measure CoQ

- Lack of data or difficulties in collecting data

- Accounting system not suitable to the measurement of CoQ

Indeed, the barriers listed above could be significant for some firms, especially the SMEs. However, quality cost information is an important input to the decision making and should not be neglected by companies that want to survive in the actual competitive environment. Accordingly, Top management should manage to overcome the barriers faced with the adoption of a suitable CoQ system and a good leading of change management.

\subsection{Quality Cost Surveys}

Over the last three decades, a number of quality costing surveys have been conducted worldwide. Table 1 show the various approach used as well as the findings identified by the researchers.

\begin{tabular}{|c|c|c|c|c|}
\hline Authors & $\begin{array}{l}\text { Survey } \\
\text { method }\end{array}$ & $\begin{array}{l}\text { Country } \\
\& \text { sample }\end{array}$ & $\begin{array}{l}\text { Response } \\
\text { rate }(\%)\end{array}$ & Findings \\
\hline $\begin{array}{l}\text { Plunkett and } \\
\text { Dale (1987) }\end{array}$ & $\begin{array}{l}\text { In-depth } \\
\text { Interviews }\end{array}$ & $\begin{array}{l}\text { UK: } 12 \text { companies } \\
\text { of pressure-vessel } \\
\text { fabrication of the } \\
\text { process plant } \\
\text { industry }\end{array}$ & 100 & $\begin{array}{l}\text { Only half of the firms provided data on quality } \\
\text { expenditures }\end{array}$ \\
\hline $\begin{array}{l}\text { Sullivan and } \\
\text { Owens } \\
(1983)\end{array}$ & $\begin{array}{l}\text { Magazine } \\
\text { questionnaires: } \\
\text { Readers of } \\
\text { quality } \\
\text { progress }\end{array}$ & 35000 readers & $\begin{array}{l}\text { Less than } \\
0.1\end{array}$ & $\begin{array}{l}\text { It has been found that management is likely to be } \\
\text { interested in quality cost reports. } \\
\text { About } 44 \text { firms provided a break up of quality cost into } \\
\text { PAF categorisation. }\end{array}$ \\
\hline Kano (1986) & Postal survey & 680 Japanese firms & 32 & $\begin{array}{l}\text { Out of } 680 \text { firms, only } 13 \text { provided actual data on } \\
\text { quality cost. The author stated that due to an } \\
\text { inefficiency of the accounting information system, } \\
\text { firms are unable to provide quality cost data. }\end{array}$ \\
\hline $\begin{array}{l}\text { Allen and } \\
\text { Oakland } \\
(1988)\end{array}$ & Postal survey & $\begin{array}{l}\text { UK: } 400 \text { firms in } \\
\text { the Textile industry }\end{array}$ & $46 \%$ & $\begin{array}{l}\text { Half of the respondents claimed to be reporting quality } \\
\text { cost and } 27 \% \text { of them provided quality cost as } \\
\text { percentage of sales revenue. }\end{array}$ \\
\hline $\begin{array}{l}\text { Singer, } \\
\text { Churchill } \\
\text { and Dale } \\
(1989)\end{array}$ & $\begin{array}{l}\text { In-depth } \\
\text { interviews }\end{array}$ & $\begin{array}{l}\text { UK: } 13 \text { Nuclear } \\
\text { supplier firms }\end{array}$ & 100 & $\begin{array}{l}\text { Only half of firms requested collet a limited amount of } \\
\text { data related to scraps and reworks }\end{array}$ \\
\hline $\begin{array}{l}\text { Sohal, Abed } \\
\text { and Kelier } \\
(1990)\end{array}$ & Mailed survey & n.a. & 26.6 & $\begin{array}{l}63 \% \text { of respondents claimed to measure quality costs. } \\
\text { Authors indicated that necessary modifications are } \\
\text { required in the existing accounting system in order to } \\
\text { facilitate the implementation of a QCS. }\end{array}$ \\
\hline $\begin{array}{l}\text { Lascelles and } \\
\text { Dale (1990) }\end{array}$ & Postal survey & $\begin{array}{l}\text { UK: } 1160 \\
\text { automotive } \\
\text { supplier's firms }\end{array}$ & 32 & $42 \%$ of the firms claimed to measure quality cost \\
\hline
\end{tabular}




\begin{tabular}{|c|c|c|c|c|}
\hline Authors & $\begin{array}{l}\text { Survey } \\
\text { method }\end{array}$ & $\begin{array}{l}\text { Country } \\
\& \text { sample }\end{array}$ & $\begin{array}{l}\text { Response } \\
\text { rate }(\%)\end{array}$ & Findings \\
\hline Chen (1992) & Postal survey & $\begin{array}{l}375 \text { Western } \\
\text { Michigan Firms } \\
\text { with sales of over } \\
1 \text { million dollars }\end{array}$ & 35 & $\begin{array}{l}38 \% \text { of respondents have an organized system for } \\
\text { collecting quality costs. Of these, } 67 \% \text { use sales as a } \\
\text { measurement base. }\end{array}$ \\
\hline $\begin{array}{l}\text { Sohal, } \\
\text { Ramsay and } \\
\text { Samson } \\
(1992)\end{array}$ & Postal survey & $\begin{array}{l}101 \text { Australien } \\
\text { firms }\end{array}$ & 51 & $\begin{array}{l}\text { Only } 42 \% \text { of respondents measured quality cost, and } \\
\text { of these } 41 \% \text { use the PAF model. }\end{array}$ \\
\hline $\begin{array}{l}\text { Kumar and } \\
\text { Brittain } \\
(1995)\end{array}$ & Postal survey & $\begin{array}{l}200 \text { British } \\
\text { manufacturing } \\
\text { companies with } \\
\text { minimum } 50 \\
\text { employees }\end{array}$ & 53.5 & $\begin{array}{l}78.3 \% \text { of British manufacturers provided information } \\
\text { about the perceived CoQ but only } 59 \% \text { them stated that } \\
\text { they presented quality cost information at management } \\
\text { review meetings. }\end{array}$ \\
\hline $\begin{array}{l}\text { Olivier and } \\
\text { Qu (1999) }\end{array}$ & Postal survey & $\begin{array}{l}400 \text { Australian } \\
\text { manufacturers } \\
\text { certified to } \\
\text { AS/NZS IS0 } 9000\end{array}$ & 34 & $\begin{array}{l}\text { The findings indicate that } 25.7 \% \text { of respondents ( } 35 \\
\text { firms out of 136) measure quality costs in some form. } \\
\text { Among the remaining } 101 \text { firms which did not measure } \\
\text { cost of quality, } 37 \text { firms }(27.2 \%) \text { indicated that they plan } \\
\text { to implement a COQ reporting system in the future, } \\
\text { and a further } 64 \text { firms }(47.1 \%) \text { had no plans to } \\
\text { implement COQ reporting in the future. }\end{array}$ \\
\hline $\begin{array}{l}\text { Halis and } \\
\text { Oztas (2002) }\end{array}$ & Postal survey & $\begin{array}{l}1100 \text { ISO-9000 } \\
\text { Certified Turkish } \\
\text { companies }\end{array}$ & 30 & $\begin{array}{l}\text { It has been determined that only } 19.1 \% \text { of companies } \\
\text { give priority to record expenditures related to quality in } \\
\text { detail. } \\
\text { The percentage of the internal and external failures are } \\
14.6 \% \text { and } 11.5 \% \text { respectively while prevention and } \\
\text { appraisal cost represent } 33.7 \% \text { and } 40.2 \% \text {. (analysis } \\
\text { according to mean values) }\end{array}$ \\
\hline Uyar (2008) & Mail survey & $\begin{array}{l}500 \text { Turkish } \\
\text { industrial } \\
\text { enterprises }\end{array}$ & 20.4 & $\begin{array}{l}\text { It has been found that almost half }(49.5 \%) \text { of } \\
\text { responding firms currently implement a COQ system. } \\
56.3 \% \text { of them expressed that they were implementing } \\
\text { more than } 5 \text { years. } \\
\text { the majority of the responses indicated that perceptions } \\
\text { of the scale of quality costs as a percentage of sales } \\
\text { turnover are centred between } 0-10 \%\end{array}$ \\
\hline $\begin{array}{l}\text { Arvaiova, } \\
\text { Aspinwall } \\
\text { and Walker } \\
(2009)\end{array}$ & Postal survey & $\begin{array}{l}\text { UK tele- } \\
\text { communication } \\
\text { companies }\end{array}$ & n.a. & $\begin{array}{l}\text { The survey results revealed little interest in } \\
\text { implementing such programmes in the sector. The most } \\
\text { frequently cited reasons were: having a costing system } \\
\text { that is already capable of monitoring quality costs; and } \\
\text { not yet introduced to the concept of CoQ. }\end{array}$ \\
\hline $\begin{array}{l}\text { Mandal and } \\
\text { Shah (2010) }\end{array}$ & $\begin{array}{l}\text { Questionnaire } \\
\text { survey }\end{array}$ & $\begin{array}{l}365 \text { manufacturing } \\
\text { firms }\end{array}$ & $36 \%$ & $\begin{array}{l}\text { The study aims to give an insight into the types of } \\
\text { quality cost data being used by Australian manufacturing } \\
\text { firms in formulating quality improvement strategies. It } \\
\text { has been found that the majority }(78 \%) \text { of the } \\
\text { respondent firms prepare in-process rejection/scrap } \\
\text { and customer feedback reports and set targets for } \\
\text { reducing rework/scrap and reducing customer } \\
\text { complaints. }\end{array}$ \\
\hline $\begin{array}{l}\text { Rasamanie } \\
\text { and } \\
\text { Kanapathy } \\
\text { (2011) }\end{array}$ & Email & $\begin{array}{l}248 \text { Malaysian } \\
\text { manufacturing } \\
\text { companies }\end{array}$ & 33.9 & $\begin{array}{l}\text { Only } 33 \text { organizations out of } 84 \text { organizations had } \\
\text { implemented COQ reporting system. Lack of } \\
\text { cooperation among departments and difficulties in } \\
\text { getting data were the top two challenges faced by these } \\
\text { organizations during the implementation of COQ. }\end{array}$ \\
\hline
\end{tabular}




\begin{tabular}{|c|c|c|c|c|}
\hline Authors & $\begin{array}{l}\text { Survey } \\
\text { method }\end{array}$ & $\begin{array}{l}\text { Country } \\
\& \text { sample }\end{array}$ & $\begin{array}{l}\text { Response } \\
\text { rate }(\%)\end{array}$ & Findings \\
\hline $\begin{array}{l}\text { Tye et al. } \\
\text { (2011) }\end{array}$ & Postal survey & $\begin{array}{l}\text { Malaysia: } 300 \\
\text { Penang } \\
\text { manufacturing } \\
\text { firms }\end{array}$ & 21 & $\begin{array}{l}83 \% \text { of the firms implement a QCS. Of these, the } \\
\text { majority of them are from the electronics and electrical } \\
\text { industry. Most of the firms }(80.7 \%) \text { specify that the } \\
\text { perception of the scale of cost of quality as a } \\
\text { percentage of annual sales is below } 10 \% \text {. }\end{array}$ \\
\hline $\begin{array}{l}\text { Ramos-Pires } \\
\text { Cociorva, } \\
\text { Saraiva, } \\
\text { Casas-Novas } \\
\text { and Rosa } \\
(2013)\end{array}$ & Postal survey & $\begin{array}{l}1131 \text { Portuguese } \\
\text { companies with iso } \\
\text { certified systems }\end{array}$ & 12.8 & $\begin{array}{l}\text { Of the } 145 \text { companies considered in the analysis, } \\
77(53.1 \%) \text { produced specific QRC reports. However, } \\
\text { only } 49.4 \% \text { of these carry out the explicit and isolated } \\
\text { identification of QRC in management reports. }\end{array}$ \\
\hline $\begin{array}{l}\text { Satanova et } \\
\text { al. (2014) }\end{array}$ & $\begin{array}{l}\text { Online } \\
\text { questionnaire }\end{array}$ & $\begin{array}{l}300 \text { Slovakian } \\
\text { SMEs }\end{array}$ & 62 & $\begin{array}{l}\text { It has been concluded that Slovak manufacturing SMEs } \\
\text { which deal with quality cost pay more attention on } \\
\text { monitoring internal and external failures } \\
\text { On the other hand, } 29 \% \text { of respondents are interested } \\
\text { in implementing a QCS, 34\% stated that they are not } \\
\text { certain and the rest 37\% did not show interest. }\end{array}$ \\
\hline $\begin{array}{l}\text { Ramos-Pires } \\
\text { et al. (2015) }\end{array}$ & $\begin{array}{l}\text { Questionnaire } \\
\text { survey }\end{array}$ & $\begin{array}{l}1272 \text { Portuguese } \\
\text { certified } \\
\text { companies }\end{array}$ & 25.4 & $\begin{array}{l}\text { In this research, authors have identified three profiles of } \\
\text { use of QRC information. one group of companies } \\
\text { prepares information about QRC but ultimately does } \\
\text { not use this information in the management process; a } \\
\text { second group of companies uses this information in } \\
\text { accordance with a diagnostic profile; a third group of } \\
\text { companies show also an interactive profile of use of } \\
\text { QRC information, which means that they are using this } \\
\text { information in an extensive way. }\end{array}$ \\
\hline $\begin{array}{l}\text { Chatzipetrou } \\
\text { and } \\
\text { Moschidis } \\
(2016)\end{array}$ & $\begin{array}{l}\text { Structured } \\
\text { questionnaire }\end{array}$ & $\begin{array}{l}159 \text { Greek } \\
\text { supermarkets }\end{array}$ & 100 & $\begin{array}{l}\text { The survey highlighted the limited use of quality costing } \\
\text { practices among supermarkets. The way companies } \\
\text { monitor quality costs proved to be highly dependent on } \\
\text { their size, the economic circumstances and other } \\
\text { variables (i.e. ISO/HACCP certification). }\end{array}$ \\
\hline $\begin{array}{l}\text { Kerfai, } \\
\text { Ghadhab } \\
\text { and } \\
\text { Malouche } \\
\text { (2016) }\end{array}$ & $\begin{array}{l}\text { Interview- } \\
\text { based survey }\end{array}$ & $\begin{array}{l}700 \text { Tunisian } \\
\text { SMEs from } \\
\text { various branches } \\
\text { of industry }\end{array}$ & 6 & $\begin{array}{l}\text { It has been found that only a minority of Tunisian } \\
\text { companies adopt a QCS in their companies. } \\
\text { Besides, it has been concluded that companies with } \\
\text { QCS experience less internal and external failures than } \\
\text { others due to the investment in prevention and appraisal } \\
\text { actions. }\end{array}$ \\
\hline $\begin{array}{l}\text { Glogovac \& } \\
\text { Filipovic } \\
(2017)\end{array}$ & $\begin{array}{l}\text { Mail } \\
\text { questionnaire }\end{array}$ & $\begin{array}{l}500 \text { Serbian } \\
\text { companies }\end{array}$ & 37.2 & $\begin{array}{l}42 \% \text { of companies do not determine their quality costs, } \\
28 \% \text { determine these costs but do not analyse them or } \\
\text { use the analysed data adequately, while } 30 \% \text { stated that } \\
\text { the level of CoQ management is quite high. }\end{array}$ \\
\hline $\begin{array}{l}\text { Moschidis, } \\
\text { Chatzipetrou } \\
\text { and Tsiotras } \\
(2018)\end{array}$ & $\begin{array}{l}\text { Online survey } \\
\text { form }\end{array}$ & $\begin{array}{l}457 \text { Food \& } \\
\text { Beverage Greek } \\
\text { companies }\end{array}$ & 23 & $\begin{array}{l}\text { The more mature a company's QMS, the more } \\
\text { emphasis they placed on appraisal quality costs and } \\
\text { effective use of quality costs information. }\end{array}$ \\
\hline
\end{tabular}

Table 1. Quality cost surveys

Thus, it can be concluded from the various survey conducted worldwide that the quality costing management is a concept that is not widely used by firms yet. No matter how great the interest of the academic community in CoQ models is, and how much theoretical information and practical advice can be found, the situation in the real world is different (Schiffauerova \& Thomson, 2006). Companies rarely have a realistic idea of how much profit they are losing through poor quality (Abdelsalam \& Gad, 2009). Quality managers use indicator to monitor quality improvement but they do not develop a separate framework to manage quality related costs (Satanova et al., 2014). 


\section{Research Approach}

This research has an exploratory nature and based on primary data gathered through a questionnaire survey applied to Moroccan industrial companies.

The aim of the study is to highlight practices or then barriers associated to quantifying quality-related costs as well as analysing relationship between the characteristics of an organisation and its practices in term of managing quality costs.

The choice of the online questionnaire as a survey methodology is due to the fact that a large sample could be realised, thus a large amount of data could be generated and as a result a high reliability of conclusions could be reached. Having selected this type of survey methodology, three major issues needed to be considered, namely the design of the sample, the design of the questionnaire and the survey procedure.

\subsection{The Sample Design}

According to the Moroccan Office of Industrial and Commercial Protection- OMPIC (barometer.directinfo.ma), 65505 manufacturing companies operate in Morocco in 2018. Due to the large size of the basic set, it was not possible to survey all Moroccan manufacturing firms, which was the reason for using a sampling through survey data.

To determine the appropriate sample size which leads to accurate results, the following formulas was applied:

$$
S s=\frac{Z^{2} *(p) *(1-p)}{c^{2}}
$$

\section{Where:}

Ss: Is the scope of the sample set

$Z$ : Is the value for the confidence level (e.g. 1.96 for $95 \%$ confidence level),

$p:$ Is the percentage picking a choice, expressed as decimal ( 0.5 used for sample size needed)

$c:$ Is the confidence interval, expressed as decimal (e.g., 0.05)

The calculation shows that the scope of the sample set should be at the level of 382 firms. To reach the required sample size based on an expected response rate $(40 \%)$, it was required to send the questionnaire to 955 manufacturers. These companies were requested to have the questionnaire responded by their quality manager, or the individual in charge of the quality management structure regardless of his title.

\subsection{Questionnaire Design}

The proposed questionnaire consisted of two sections (see figure 1). The first section includes 11 questions with 9 questions about the companies' characteristics such as company size, origin, age, type of activity, business market orientation, QMS implementation, QMS maturity level, and certifications obtained.

The tenth question-Q10 involve obtaining respondent's opinion about the need or not to calculate quality-related costs in their organization.

The Q11 "Do you calculate COQ in your organization?" is the main question of the survey and which redirect toward the second section. Depending on the answer to this question, the respondent goes to either subsection 2.1 or subsection 2.2.

The subsection 2.1 deals with identification of organisations' practices in the area of managing quality costs. It includes questions about:

- The CoQ scale;

- The components considered in the calculation of the total quality cost;

- The model used for identifying quality-related costs; 
- The organisation level in whish quality costs are managed;

- The frequency of COQ calculation and reporting;

- And others.

While subsection 2.2. focuses on understanding the barriers to the implementation of a CQS and how they manage their quality program. It includes questions about:

- Barriers to the implementation of QCS;

- Techniques used to prioritize the improvement activities and develop a quality program;

- Strategies adopted to steer and justify the annual quality budget;

- And others.

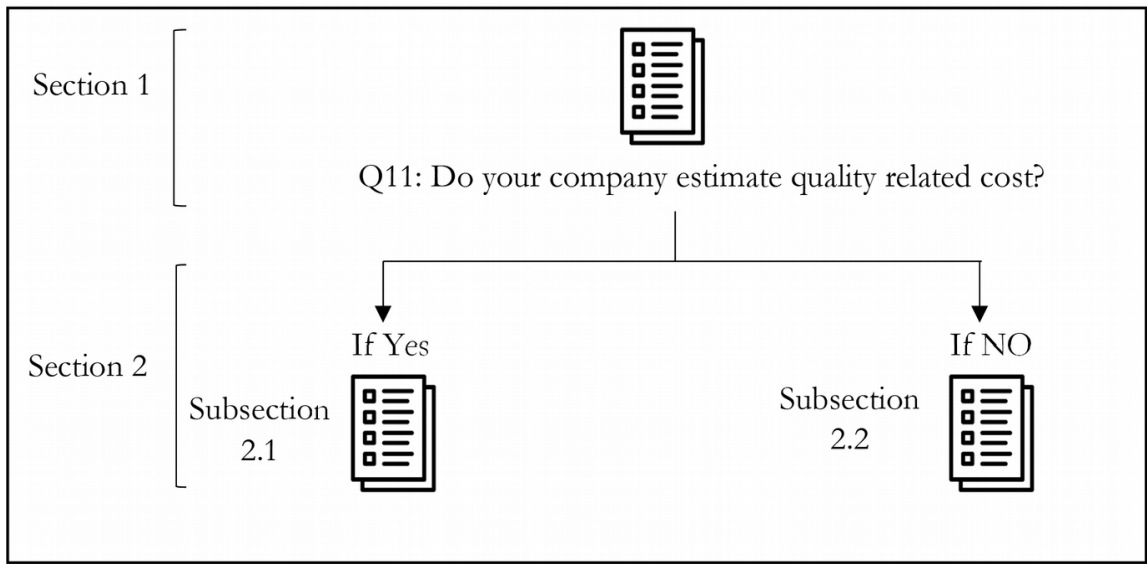

Figure 1. The questionnaire design

Most of the questions are of closed type, with multiple choice answers, while a small number of them are dichotomous or multiple-choice questions with the option "Other" that allows to respondents to clarify specific answers.

Before launching the survey, it was necessary to make a pretesting of the questionnaire in order to detect any problem that might lead to biased answers such as: misinterpretation of questions, inability to answer a question, etc.

The questionnaire was tested on 12 respondents who provided feedback on its understandability, clarity of questions as well as the time needed to complete it.

\subsection{Data Analysis}

Data obtained were analysed using IBM SPSS Statistics 22 software. Firstly, descriptive statistics are used to describe the basic features of the data in the study and to provide simple summaries about the sample.

Secondly, a chi-square test of independence was used to determine whether some variables were dependent of others. The chi-square test of independence involves two variables, such as groups and conditions/categories, and seeks to determine whether one variable is independent of the other.

\section{Results}

\subsection{Respondent Organizations' Profile}

The questionnaires were distributed and also collected electronically to 1000 industrial company (on-line questionnaire). The ratio of questionnaire return was $23.4 \%$, which mean 234 completed questionnaires. The reduced number of the sample set influenced the error of estimation, which rose to $6.39 \%$ 
The respondent organizations belonged to 13 different industrial sectors. The highest response rate was from the automotive and machinery industry (24.8\%), second highest was from the food and beverage industry $(23.1 \%)$ and the third highest was from the chemicals industry $(15 \%)$.

The data obtained showed that $52.1 \%$ of respondent organisations were large industrial firms with over than 200 employees, $25.6 \%$ mid-sized having between 50 to 200 employees, $16.2 \%$ were small companies having between 10 and 50 employees and 6\% were micro firms with less than 10 employees. It is also founded that $54.3 \%$ were domestic companies while $45.7 \%$ were international organisations. $50.9 \%$ of respondents' organisations were offshore firms and $49.1 \%$ were companies that operates only at the national level.

In terms of duration of business, $26.1 \%$ of the firms have been in the business for more than 40 years, $20.5 \%$ between 20 to 39 years while $53.4 \%$ have been in the business for less than 20 years.

In response to whether or not companies have a QMS, $79.9 \%$ of the respondents did. Furthermore, $61.6 \%$ of them indicated that their quality management system was certified according to ISO.

\subsection{Descriptive Statistics: Practices of Moroccan Industries in the Area of Managing Quality Costs}

\section{Finding 1: More than half of Moroccan industrial companies do not adopt a QCS}

Among surveyed businesses, 35.5\% claimed to have a QCS implemented while 64.5\% stated to not have a QCS implemented yet. This result appears quite disappointing while recent researches reported a higher rate of adoption of the concept.

In opposition, the statistics reveal a very high level of consciousness about the significance of quality costs. In fact, when respondents were asked "Do you see it's interesting to monitor QRC?", $76.9 \%$ out of the 234 surveyed firms affirmed "Yes", $18.4 \%$ stated that they are "Not Certain", and the rest, which is only $4.7 \%$ did not show any interest on managing QRC within the enterprises at all.

On the whole, it may be concluded that Moroccan industrials companies are aware of the importance of managing QRC but are still not practicing this approach yet. (See barriers to the implementation of QCS in finding 8)

\section{Finding 2: The automobile and machinery industry tops the list in implementing COQ}

The data obtained shows that Automotive and machinery industry scores top in implementing QCS (44.6\%), followed by food and beverage $(20.5 \%)$ and then aviation industries $(9.6 \%)$. Contrarily, the oil, textile and railway industry are clustered at the bottom of the ranking.

\section{Finding 3: The scale of quality costs as stated by most of Moroccan firms range from 5 to $15 \%$ of sales} revenues

Respondents that stated to have a QCS implemented were asked to provide information about the scale of quality costs at their companies. The following seven options were proposed:

(1) Less than 5 percent;

(2) 5-10 percent;

(3) 10-15 percent;

(4) 15-20 percent;

(5) 20-25 percent;

(6) 25-30 percent and

(7) more than 30 percent.

The analysis of the responses is as follows (Table 1): The statistics indicate that $39.8 \%$ of respondents chose the option less than 5\%,20.5\% chose the option between $5 \%$ and $10 \%, 15.7 \%$ chose the option between 10 and $15 \%$ and $12 \%$ chose the option between 15 and 20\%. according to (Uyar, 2008; Williams, Van der Wiele \& Dale, 1999) state that the CoQ scale is likely to range from 5 to 25 percent. Tye et al. (2011) concluded that 
this scale could be changeable depending on the industry type, company size, maturity of QMS, and other considerations.

Also, the CoQ scale is changeable because the structure of CoQ models often differs substantially between companies. Every quality cost system is usually adjusted and different elements are included or left out of the calculations.

\begin{tabular}{|l|r|r|}
\hline \multicolumn{1}{|c|}{ CoQ range (\%) } & Frequency & \multicolumn{2}{c|}{ Percentage } \\
\hline Less than $5 \%$ & 33 & 39.8 \\
\hline Between 5 and $10 \%$ & 17 & 20.5 \\
\hline Between 10 et $15 \%$ & 13 & 15.7 \\
\hline Between 15 and $20 \%$ & 10 & 12 \\
\hline Between 20 and $25 \%$ & 6 & 7.2 \\
\hline Between 25 and 30\% & 2 & 2.4 \\
\hline Over than 30\% & 2 & 2.4 \\
\hline Total & 83 & 100.0 \\
\hline
\end{tabular}

Table 2. The CoQ scale

\section{Finding 4: Most businesses tend to measure QRC in All or almost processes}

Respondents were asked to give information about the parts of organisation in which quality costs are managed. The results show that $49.4 \%$ of firms manage QRC at all or almost processes, $26.5 \%$ monitor quality costs in production and some other processes while $24.1 \%$ control theses costs only in the framework of production process.

\section{Finding 5: Most businesses tend to use the "Process model" to monitor their QRC}

Table 3 shows the models used by firms to monitor QRC. The results postulate that $63.9 \%$ of businesses that claimed to have an implemented QCS are using the "Process model" to manage their quality costs. This can be justified by the fact that most of firms are adopting the process approach in managing their organisations.

\begin{tabular}{|l|r|r|}
\hline \multicolumn{1}{|c|}{ CoQ Model } & Frequency & \multicolumn{1}{c|}{ Percentage } \\
\hline PAF model & 10 & 12.0 \\
\hline Process model & 53 & 63.9 \\
\hline Opportunity model & 2 & 2.4 \\
\hline ABC model & 9 & 10.8 \\
\hline Hybrid or personalised model & 9 & 10.8 \\
\hline Total & 83 & 100.0 \\
\hline
\end{tabular}

Table 3. Distribution of CoQ Model

Finding 6: Environmental, social and project non-quality related costs are the less integrated components to the calculation of Cost of Non-Quality (CNQ)

As shown in Table 4, cots related to non-compliant product followed by overconsumption, stock management and Supplier are the common used components to calculate CNQ while the project, environmental and social non-quality related costs are the less used elements. Yet these aspects must be taken into consideration because they constitute a large part of company's losses. Not introducing these aspects could skew the result of CNQ calculation, thus the CoQ and as consequence the decisions to be made. 


\begin{tabular}{|l|r|r|}
\hline \multicolumn{1}{|c|}{ CNQ Categories } & Frequency & Percentage \\
\hline Non-compliant Product (rejects, rework, repairs, discounts / penalties, warranty client, etc.) & 86 & 34.5 \\
\hline Stock management (Excess stock, storage of obsolete product, urgent orders, etc.) & 42 & 16.8 \\
\hline Over-consumption (Energy, product, etc.) & 37 & 14.8 \\
\hline Supplier non-quality & 26 & 10.4 \\
\hline Environnemental non-quality (pollution, noise, etc.) & 19 & 7.6 \\
\hline Social non-quality (Work accident, absenteeism, demotivation, presenteeism, etc.) & 20 & 8 \\
\hline Gap between expected cost and final cost of a project & 19 & 7.6 \\
\hline
\end{tabular}

Table 4. CoQ components

\section{Finding 7: CoQ metrics are calculated and communicated in a monthly frequency}

To gain insight into the use of information provided by the COQ reporting system, a set of questions was asked; the frequency of reporting; who within the organization the reports are communicated; and the purpose for which the information was used.

The statistics indicate that the CoQ is mainly measured monthly (55.4\% of respondents measure CoQ monthly, $26.5 \%$ quarterly while $8.4 \%$ and $6.9 \%$ do so semi-annually and annually, respectively).

Besides, it has been found that QRC metrics are principally communicated to "Top management" (43.1\%) followed by "Quality committee" (40.8\%) and "All employees" (16.2\%).

In term of using QRC information, $88 \%$ of respondents establish a plan to analyse the results and generate improvement activities while $12 \%$ do not use QRC information to the management process.

Indeed, the quality costing perspectives are not limited to the identification and measurement of CoQ. The main objective of a QRC system is to reduce costs through the identification of improvement opportunities.

In line with this, Pires et Al. (2015) identified three groups of companies with different profiles of use of QRC information: one group of companies prepares information about QRC but ultimately does not use this information in the management process; a second group of companies uses this information in accordance with a diagnostic profile; a third group use this information in an extensive way.

Finding 8: The primary barriers for COQ implementation is the complexity in implementing a QCS

Among the reasons that keep a business from implementing the COQ system, as shown in Table 5, "Complexity in implementing a QCS: No satisfactory guidelines" top the list (40.5\%), followed by "Lack of knowledge of COQ principles" (21.1\%) and "Difficulties in collecting data" (10.9\%). Right after them, "Insufficient budget" (9.9\%) and "Employees are reluctant to support" (8.6\%).

Then, "No interest on implementing QCS. The current system is capable to identify effective quality improvement area" takes a share of $5.3 \%$ and "Insufficient staff" is placed at the last ranking with a percentage of $3.9 \%$.

\begin{tabular}{|l|r|r|}
\hline \multicolumn{1}{|c|}{ Barrier } & Frequency & Percentage \\
\hline Complexity in implementing a QCS: No satisfactory guidelines & 123 & 40.5 \\
\hline Lack of knowledge of COQ principles & 64 & 21.1 \\
\hline Difficulties in collecting data & 33 & 10.9 \\
\hline Insufficient budget & 30 & 9.9 \\
\hline Employees are reluctant to support & 26 & 8.6 \\
\hline $\begin{array}{l}\text { No interest on implementing QCS. The current system is capable to identify effective quality } \\
\text { improvement area }\end{array}$ & 16 & 5.3 \\
\hline Insufficient staff & 12 & 3.9 \\
\hline Total & 304 & 100 \\
\hline
\end{tabular}

Table 5. Barriers to the implementation of QCS 
Finding 9: The majority of firms without QCS use usual key Performance indicator (KPI) to prioritise their quality improvement activities and quality expenditures of previous year as basis to estimate their annual quality budget

The results shown in Table 6 indicate that quality managers use mostly key performance indicators (Reject Ratio, Number of complaints, $\% \mathrm{OEE}, \%$ Breakdown, etc.) as basis to the generation of quality improvement activities included in the annual quality program. Firms are proceeding with quality improvement programmes without a well-defined quality cost system.

Furthermore, it has been found that the majority $(76.5 \%)$ of quality managers use quality expenditures of last year as basis to estimate their annual quality budget.

However, to better control costs and improve performance it is required to promote actions allowing cost reduction which can't be reached with the only use of KPIs. In fact, introducing CoQ metrics facilitates prioritising improvement areas and justifying the investment that should be made. Thus, quality managers should develop a separate framework for measuring and evaluating QRC.

\begin{tabular}{|l|c|c|}
\hline \multicolumn{1}{|c|}{ Methodology } & Frequency & Percentage \\
\hline Using usual KPI & 121 & 69.1 \\
\hline According to investment and ROI & 32 & 18.3 \\
\hline Depending to the budget & 22 & 12.6 \\
\hline
\end{tabular}

Table 6. Techniques used to prioritise improvement activities

\subsection{Factor Analysis}

\section{(A) Factors affecting the establishment of CoQ system}

H1: The implementation of QCS depends on the basic characteristics of a company, such as business activity, origin, age, size, business market and the possession of certifications.

H2: The level of QMS maturity has a statistical correlation with the implementation of QCS. In other words, companies with a higher level of QMS maturity tend to implement a quality costing system.

According to the results of Pearson chi-square test, the origin and business activity are proven to be characteristics that have a statistically significant relationship with the implementation of CoQ reporting system $(\mathrm{p}<0.001$ in the two cases).

The assumption that business market orientation affects the QCS implementation is also proved $(p<0.001$ and phi $=0.318$ ). In fact, $72.3 \%$ of the total number of companies that quantify quality costs are oriented towards the multinational business segment, while $27.7 \%$ are oriented towards the domestic business segment. Offshore firms tend to monitor quality cost due to the fact that customers of the foreign markets are more demanding for quality as well as for the prices. Therefore, those companies have to measure their performance and enhance continuously their processes.

Besides, it has been found that company's size is a characteristic that have a positive relationship $(p=0.012)$ while the age has no influence on managing quality costs with an organisation $(p>0.05)$

With regard to Possession or lack of ISO certification, sample data do not show any differences between companies that quantify their quality related costs and those that do not $\left(X^{2}=1.646\right.$ and $\left.p=0.200\right)$ (Cross-tabulation in shown in Table 7)

Indeed, many authors (Jaju, Mohanty, \& Lakhe, 2009; Djekic, Zaric \& Tomic, 2014; Martinez \& Selles, 2015) point out that quality costs are related to the quality management system and other researchers (Chiarini, 2015; Glogovac \& Filipovic, 2017) have even analysed the connection between the effectiveness of CoQ management and ISO 9001:2015 requirements. 
It is obvious that fulfilling the basic requirements of ISO 9001 is important for the adequacy of quality cost management. However, it doesn't necessarily mean that companies with a QCS implemented are an ISO certificated and vice versa.

It is observed that some firms with higher quality practices are still not interested/ registered ISO 9001 while many certified companies are not implementing a QCS (see finding 8: barriers to the implementation of a QCS).

\begin{tabular}{|l|c|c|c|}
\multirow{2}{*}{\begin{tabular}{c}
\multirow{2}{*}{ ISO } \\
Certification
\end{tabular}} & \multicolumn{2}{|c|}{ CoQ calculation } & \multirow{2}{*}{ Total } \\
\cline { 2 - 4 } & No & Yes & 44 \\
\cline { 1 - 4 } No & 30 & 14 & $32.5 \%$ \\
\hline \multirow{2}{*}{ Yes } & $26.8 \%$ & $18.7 \%$ & 143 \\
& 82 & 61 & $76.5 \%$ \\
\hline \multirow{2}{*}{ Total } & $73.2 \%$ & $81.3 \%$ & 18 \\
& 112 & 75 & $100 \%$ \\
\hline
\end{tabular}

Table 7. ISO Certification * CoQ calculation Cross-tabulation

Research Hypothesis (H2) examined whether the decision to implement a QCS changes in a systematic way as an organization's quality system matures. We considered five levels of the companies' QMS Maturity (Crosby's quality management maturity grid). The lowest stage of maturity is called 'Uncertainty', the organisation is inexperienced, quality management is a low priority then as quality management matures it goes through the stages of 'Awakening', 'Enlightenment', 'Wisdom', then the highest level 'Certainty' on which quality management is considered as a vital part of the organization.

The results $(p<0.001)$ proved the assumption that QMS maturity positively affect the establishment of CoQ reporting system in the organisation. In fact, the lowest level means that quality costs are not identified and gathered, while the highest-level means that these costs are identified, analysed, and properly used for the purpose of improvement. (Cross-tabulation shown in Table 8).

\begin{tabular}{|l|c|c|c|}
\hline \multirow{2}{*}{ QMS } & \multicolumn{2}{|c|}{ CoQ calculation } & \multirow{2}{*}{ Total } \\
\cline { 2 - 3 } maturity level & No & Yes & 39 \\
\hline \multirow{2}{*}{ Uncertainty } & 37 & 2 & $20.9 \%$ \\
\hline \multirow{2}{*}{ Awakening } & $33.0 \%$ & $2.7 \%$ & 34 \\
& 30 & 4 & $18.2 \%$ \\
\hline \multirow{2}{*}{ Enlightenment } & $28.8 \%$ & $5.3 \%$ & 37 \\
& $20.5 \%$ & $18.7 \%$ & $19.8 \%$ \\
\hline \multirow{2}{*}{ Wisdom } & 14 & 19 & 33 \\
& $12.5 \%$ & $25.3 \%$ & $17.6 \%$ \\
\hline \multirow{2}{*}{ Certainly } & 8 & 36 & 44 \\
\hline \multirow{2}{*}{ Total } & $7.1 \%$ & $48.0 \%$ & $23.5 \%$ \\
\hline
\end{tabular}

Table 8. QMS Maturity * CoQ calculation Cross-tabulation

\section{(B) Factors affecting the level of establishment of CoQ system}

H3: The level of implementation of QCS depends on the basic demographic characteristics of a company such as business activity, origin, age, size and business market. 
H4: The level of implementation of QCS has a statistically significant relationship with the level of QMS maturity. This means that companies with higher level of QMS maturity tend to manage quality costs in all or almost all of their processes and not only on the basic process.

In line with the previous hypothesis (A), the research question was raised to whether there is a statistical correlation between the level of organisation on which quality costs are managed and company's characteristic and QMS maturity level.

The result proved that only the business market has a statistically significant relationship with the parts of organisation on which quality costs are managed $(p=0.0002)$ while the other characteristics (origin, age, company's size, business activity and certifications) don't affect the level of CoQ management ( $\mathrm{p}>0.05)$.

Furthermore, the results $(p=0.01)$ proved that the assumption that QMS maturity has a statistical relationship with the le level of managing QRC. In fact, it is observed that companies with high QMS maturity level tend to manage QRC "in all or almost all processes" (67.5\% of respondents with QCS implemented), companies with a middle QMS maturity level manage quality costs "in the framework of the production process" or "in production and some other processes" while those with a low QMS maturity level already doesn't manage quality costs (Table 9).

\begin{tabular}{|c|c|c|c|c|}
\hline \multirow[b]{2}{*}{$\begin{array}{l}\text { QMS } \\
\text { maturity level }\end{array}$} & \multicolumn{3}{|c|}{ CoQ level of implementation } & \multirow[b]{2}{*}{ Total } \\
\hline & $\begin{array}{l}\text { Only in the production } \\
\text { process }\end{array}$ & $\begin{array}{c}\text { In production and some } \\
\text { other processes }\end{array}$ & $\begin{array}{l}\text { In all or almost } \\
\text { processes }\end{array}$ & \\
\hline Uncertainty & $\begin{array}{c}1 \\
7.1 \%\end{array}$ & $\begin{array}{c}0 \\
0.0 \%\end{array}$ & $\begin{array}{c}1 \\
2.5 \%\end{array}$ & $\begin{array}{c}2 \\
2.7 \%\end{array}$ \\
\hline Awakening & $\begin{array}{c}2 \\
14.3 \%\end{array}$ & $\begin{array}{c}2 \\
9.5 \%\end{array}$ & $\begin{array}{c}0 \\
0.0 \%\end{array}$ & $\begin{array}{c}4 \\
5.3 \%\end{array}$ \\
\hline Enlightenment & $\begin{array}{c}5 \\
35.7 \%\end{array}$ & $\begin{array}{c}4 \\
19.0 \%\end{array}$ & $\begin{array}{c}5 \\
12.5 \%\end{array}$ & $\begin{array}{c}14 \\
18.7 \%\end{array}$ \\
\hline Wisdom & $\begin{array}{c}5 \\
35.7 \% \\
\end{array}$ & $\begin{array}{c}7 \\
33.3 \% \\
\end{array}$ & $\begin{array}{c}7 \\
17.5 \%\end{array}$ & $\begin{array}{c}19 \\
25.3 \%\end{array}$ \\
\hline Certainly & $\begin{array}{c}1 \\
7.1 \%\end{array}$ & $\begin{array}{c}8 \\
38.1 \% \\
\end{array}$ & $\begin{array}{c}27 \\
67.5 \%\end{array}$ & $\begin{array}{c}36 \\
48.0 \%\end{array}$ \\
\hline Total & $\begin{array}{c}14 \\
100.0 \%\end{array}$ & $\begin{array}{c}21 \\
100.0 \%\end{array}$ & $\begin{array}{c}40 \\
100.0 \%\end{array}$ & $\begin{array}{c}75 \\
100.0 \%\end{array}$ \\
\hline
\end{tabular}

Table 9. CoQ level implementation* QMS Maturity level Cross-tabulation

\section{(C) Factors affecting $\operatorname{CoQ}$ scale}

H5: The scale of quality is changeable depending on QMS maturity level.

Research Hypothesis (H7) was raised to examine whether the scale of quality costs changes in a systematic way as an organization's quality system matures. Analysis of the results, presented in Table 10, singled out that QMS maturity level positively affects the scale of CoQ $(p<0.001)$. The lowest level means that the CoQ can reach higher scale while the highest level of QMS maturity means that CoQ is below $5 \%$ of sales revenue. 


\begin{tabular}{|c|c|c|c|c|c|c|c|c|}
\hline \multirow{2}{*}{$\begin{array}{c}\text { QMS } \\
\text { maturity level }\end{array}$} & \multicolumn{7}{|c|}{ CoQ level of implementation } & \multirow[b]{2}{*}{ Total } \\
\hline & $<5 \%$ & $5-10 \%$ & $10-15 \%$ & $15-20 \%$ & $20-25 \%$ & $25-30 \%$ & $>30 \%$ & \\
\hline Uncertainty & $\begin{array}{c}1 \\
3.4 \%\end{array}$ & $\begin{array}{c}0 \\
0.0 \%\end{array}$ & $\begin{array}{c}0 \\
0.0 \%\end{array}$ & $\begin{array}{c}1 \\
11.1 \%\end{array}$ & $\begin{array}{c}0 \\
0.0 \%\end{array}$ & $\begin{array}{c}0 \\
0.0 \%\end{array}$ & $\begin{array}{c}0 \\
0.0 \%\end{array}$ & $\begin{array}{c}2 \\
2.7 \%\end{array}$ \\
\hline Awakening & $\begin{array}{c}0 \\
0.0 \%\end{array}$ & $\begin{array}{c}3 \\
17.6 \%\end{array}$ & $\begin{array}{c}0 \\
0.0 \%\end{array}$ & $\begin{array}{c}1 \\
11.1 \%\end{array}$ & $\begin{array}{c}0 \\
0.0 \%\end{array}$ & $\begin{array}{c}0 \\
0.0 \%\end{array}$ & $\begin{array}{c}0 \\
0.0 \%\end{array}$ & $\begin{array}{c}4 \\
5.3 \%\end{array}$ \\
\hline Enlightenment & $\begin{array}{c}2 \\
6.9 \%\end{array}$ & $\begin{array}{c}1 \\
5.9 \%\end{array}$ & $\begin{array}{c}2 \\
15.4 \%\end{array}$ & $\begin{array}{c}6 \\
66.7 \%\end{array}$ & $\begin{array}{c}3 \\
75.0 \%\end{array}$ & $\begin{array}{c}0 \\
0.0 \%\end{array}$ & $\begin{array}{c}0 \\
0.0 \%\end{array}$ & $\begin{array}{c}14 \\
18.7 \%\end{array}$ \\
\hline Wisdom & $\begin{array}{c}5 \\
17.2 \%\end{array}$ & $\begin{array}{c}4 \\
23.5 \%\end{array}$ & $\begin{array}{c}8 \\
61.5 \% \\
\end{array}$ & $\begin{array}{c}1 \\
11.1 \%\end{array}$ & $\begin{array}{c}0 \\
0.0 \%\end{array}$ & $\begin{array}{c}0 \\
0.0 \%\end{array}$ & $\begin{array}{c}1 \\
50.0 \% \\
\end{array}$ & $\begin{array}{c}19 \\
25.3 \%\end{array}$ \\
\hline Certainly & $\begin{array}{c}21 \\
72.4 \%\end{array}$ & $\begin{array}{c}9 \\
52.9 \% \\
\end{array}$ & $\begin{array}{c}3 \\
23.1 \% \\
\end{array}$ & $\begin{array}{c}0 \\
0.0 \%\end{array}$ & $\begin{array}{c}1 \\
25.0 \%\end{array}$ & $\begin{array}{c}1 \\
100.0 \%\end{array}$ & $\begin{array}{c}1 \\
50.0 \%\end{array}$ & $\begin{array}{c}36 \\
48.0 \%\end{array}$ \\
\hline Total & $\begin{array}{c}29 \\
100.0 \%\end{array}$ & $\begin{array}{c}17 \\
100.0 \%\end{array}$ & $\begin{array}{c}13 \\
100.0 \%\end{array}$ & $\begin{array}{c}9 \\
100.0 \%\end{array}$ & $\begin{array}{c}4 \\
100.0 \%\end{array}$ & $\begin{array}{c}1 \\
100.0 \%\end{array}$ & $\begin{array}{c}2 \\
100.0 \%\end{array}$ & $\begin{array}{c}75 \\
100.0 \%\end{array}$ \\
\hline
\end{tabular}

Table 10. CoQ Scale * QMS Maturity level cross-tabulation

\section{Conclusion and Discussion}

Quality is widely recognized as a key competitive weapon to survive in the global marketplace. As costs related to quality constitute a significant portion of the company's sales revenue, it is required to quantify these costs so that the company could more easily identify quality-related problems and improve its performance.

In order to investigate whether Moroccan industrial companies manage their quality related costs, and analyze the factors that influence their decisions and practices, the above research was conducted.

In fact, the present paper offers a first insight into the quality costing management practices of Moroccan industrial enterprises, a field that has not been studied in the literature. The result of this research indicates that the implementation of COQ reporting system is not widespread as some would believe. The majority of respondents do not adopt this approach into their organizations despite the fact that they are aware of the importance of quantifying quality costs. As indicated by firms, the most frequently cited reason that encounter an organization from quantifying QRC is the complexity of the implementation which is not that easy due to the absence of satisfactory COQ implementation and execution guidelines.

This research revealed that about $76 \%$ of companies with quality cost reporting system implemented are having a CoQ scale that is below of 15 percent per sales revenue. This finding is in accordance with the literature where the scale varies from 0 to 25 percent.

In term of companies' practices in the area of managing QRC, more than half of respondents monitor QRC in all or almost all processes. Additionally, most of companies quantify quality costs using the process model while the opportunity model is the less used one.

The statistics indicated that the CoQ is mainly measured and communicated monthly. Nonetheless, in most cases the CoQ metrics and reports are communicated exclusively to Top management or/ and quality committee and not to all employees. This means that QRC information are not used to arise awareness of the potential effects of poor quality on the results.

On the other hand, companies that do not manage QRC use mostly usual key performance indicators as a basis to the generation of quality improvement activities. Firms are proceeding with quality improvement programs without a formal quality cost system.

Furthermore, the aim of this paper was to investigate the difference in characteristics of Moroccan industrial companies depending on whether they quantify their quality costs or not. The results of the study have shown that mostly large offshore companies quantify quality costs. Indeed, the customers of foreign market are demanding for 
quality as well as for the prices. Therefore, those companies have to measure their performance and improve continuously both their organization and their processes.

As for the certifications, ISO/HACCP certification does not necessarily mean that quality costing system is implemented. It was statistically proved that there is no significant relationship between certifications and the use of quality costing methods. Quality management systems provide the framework for establishing and maintaining certain quality standards, by putting emphasis on processes rather than on cost analysis.

The outcome of the chi-square test analysis leads also to the conclusion that the QMS maturity level have a strong significant correlation with the implementation of quality cost methods, the level of organization on which QRC are managed and the CoQ scale.

On the whole, it would appear that the implementation of quality cost practices in Morocco is still in the early stages. Only larger firms and those firms facing strong import competition are more likely to have higher degrees of implementation.

In fact, quality cost management should be part of a firm's quality management system. In ISO/TS16949, clause 5.6 on management review, it is stated that part of the management review should be the monitoring of quality objectives, and the regular reporting and evaluation of the cost of poor quality.

Surely, managing the cost of quality is useful for any QMS - automotive or otherwise. It is unfortunate that the ISO 9000 series has not integrated it yet in its guidelines. This inclusion would greatly enhance the awareness on COQ practices and endorse the implementation of COQ in organizations.

The major limitation of the study is that these results are valid for industrial companies in Morocco. Future researches and case studies should be conducted to cover a bigger sample size from manufacturing and services sector as well with the aim to identify ways to overcome difficulties, reveal best practices and key factors for successful QCS implementation.

\section{Acknowledgements}

The authors would like to express their sincere gratitude to all the companies who participated in the survey that formed the basis for this article.

\section{Declaration of Conflicting Interests}

The authors declared no potential conflicts of interest with respect to the research, authorship, and/or publication of this article.

\section{Fundings}

The authors received no financial support for the research, authorship, and/or publication of this article.

\section{References}

Abdelsalam, H.M.E., \& Gad, M.M. (2009). Cost of quality in Dubai: An analytical case study of residential construction projects. International Journal of Project Management, 27(5), 501-511.

https://doi.org/10.1016/j.jiproman.2008.07.006

Allen, N., \& Oakland, J.S. (1988). Quality Assurance in the Textile Industry: Part I. International Journal of Quality \& Reliability Management, 5(5), 25-37. https://doi.org/10.1108/eb002916

Arvaiova, M., Aspinwall, E.M., \& Walker, D.S. (2009). An initial survey on the use of costs of quality programmes in telecommunications. The TQM Journal, 21(1), 59-71. https://doi.org/10.1108/17542730910924754

Chatzipetrou, E., \& Moschidis, O. (2016). Quality costing: a survey in Greek supermarkets using multiple correspondence analysis. International Journal of Quality \& Reliability Management, 33(5), 615-632.

https://doi.org/10.1108/IJQRM-01-2014-0004 
Chen, F. (1992). Survey of Quality in Western Michigan Firms. International Journal of Quality \& Reliability Management, 9(4). https://doi.org/10.1108/02656719210010712

Chiarini, A. (2015). Effect of ISO 9001 non-conformity process on cost of poor quality in capital intensive sectors. International Journal of Quality \& Reliability Management, 32(2), 144-155. https://doi.org/10.1108/IJQRM-03-2013-0041

Chopra, A., \& Singh, B.J. (2015). Unleashing a decisive approach to manage quality costs through behavioural investigation. Business Process Management Journal, 21(6), 1206-1223. https:/ /doi.org/10.1108/BPMJ-07-2014-0064

Djekic, I., Zaric, V., \& Tomic, J. (2014). Quality costs in a fruit processing company: A case study of a Serbian company. Quality Assurance and Safety of Crops \& Foods, 6(1), 95-103. https://doi.org/10.3920/QAS2012.0200

Feigenbaum, A.V. (1956). Total quality control. Harvard Business Review.

Glogovac, M., \& Filipovic, J. (2017). Quality costs in practice and an analysis of the factors affecting quality cost management. Total Quality Management \& Business Excellence, 29(13-14), 1521-1544.

http://dx.doi.org/10.1080/14783363.2016.1273105

Halis, M., \& Oztas, A. (2002). Quality cost analysis in ISO-9000-cerified Turkish companies. Managerial Auditing Journal, 17(1/2), 101-104.

Jaju, S.B., Mohanty, R.P., \& Lakhe, R.R. (2009). Towards managing quality cost: A case study. Total Quality Management \& Business Excellence, 20(10), 1075-1094. https://doi.org/10.1080/14783360903247122

Juran, J.M. (1951). Quality Control Handbook (first ed.). New York: McGraw Hill.

Kano, N. (1986). Quality and economy more emphasize the role of quality on sales rather than on cost.

Kerfai, N., Ghadhab, B.B., \& Malouche, D. (2016). Performance measurement and quality costing in Tunisian manufacturing companies. The TQM Journal, 28(4), 588-596. https://doi.org/10.1108/TQM-10-2013-0119

Kumar, K., \& Brittain, J.C. (1995). Cost of quality: evaluating the health of British manufacturing industry. The TQM Magazine, 7(5), 50-57. https://doi.org/10.1108/09544789510098641

Lascelles, D.M., \& Dale, B.G. (1990). The use of quality management techniques. Quality Forum, 16, $188-192$.

Mandal, P., \& Shah, K. (2010). An analysis of quality costs in Australian manufacturing firms. Total Quality Management, 13(2), 175-182. https://doi.org/10.1080/09544120120102414

Martinez, J. M. B., \& Selles, M.E.S. (2015). A fuzzy quality cost estimation method. Fuzzy Sets and Systems, 266(May), 157-170. https://doi.org/10.1016/j.fss.2014.12.014

Morse, W. (1993). A handle on quality costs. Cambridge Managerial Accounting, 67(1), 21-24.

Moschidis, O., Chatzipetrou, E., \& Tsiotras, G. (2018). Quality costing and quality management maturity in Greece: An exploratory multi-dimensional data analysis. International Journal of Productivity and Performance Management, 67(1), 171-191. https://doi.org/10.1108/IJPPM-08-2016-0152

Oliver, J., \& Qu, W. (1999). Cost of quality reporting: Some Australian evidence. International Journal of Applied Quality Management, 2(2), 233-250. https://doi.org/10.1016/S1096-4738(99)80092-X

Plunkett, J.J., \& Dale, B.G. (1987). A review of the literature on quality-related costs. International Journal of Quality \& Reliability Management, 4(1), 40-52. https:/ /doi.org/10.1108/eb002874

Ramos-Pires, A., Cociorva, A., Saraiva, M., Casas-Novas, J., \& Rosa, Á. (2013). Management of quality-related costs. The case of Portuguese companies. Total Quality Management \& Business Excellence, 24(7-8), 782-796. http://dx.doi.org/10.1080/14783363.2013.792993

Ramos-Pires, A., Novas, J., Saraiva, M., \& Coelho, A. (2015). How companies use the information about quality-related costs. Total Quality Management \& Business Excellence, 28(5-6), 501-521.

https://doi.org/10.1080/14783363.2015.1099427 
Rasamanie, M. \& Kanapathy, K. (2011). The Implementation of Cost of Quality (COQ) Reporting System in Malaysian Manufacturing Companies: Difficulties Encountered and Benefits Acquired. International Journal of Business and Social Science, 2(6), 243-247.

Satanova, A., Zavadsky, J., Sedliacikova, M., Potkany, M., Zavadska, Z., \& Holikova, M. (2014). How Slovak small and medium manufacturing enterprises maintain quality costs: an empirical study and proposal for a suitable model. Total Quality Management \& Business Excellence, 26(11-12), 1146-1160.

https://doi.org/10.1080/14783363.2014.916477

Schiffauerova A., \& Thomson V. (2006). Managing cost of quality: insight into industry practice. The TQM Magazine, 18(5), 542-550. https://doi.org/10.1108/09544780610685502

Singer, A.J., Churchill, G.F., \& Dale, B.G. (1989). Quality costing: a state of the study in the nuclear supplier industry. Quality Assurance, 152, 67-71.

Sohal, A., Ramsay, L., \& Samson, D. (1992). Quality management practices in Australian industry. Total Quality Management, 3(3), 283-300. https://doi.org/10.1080/09544129200000035

Sohal, A.S., Abed, M.H., \& Kelier, A.Z. (1990). Quality assurance: status, structure and activities in manufacturing sectors in the United Kingdom. Quality Forum, 16, 38-49.

Sullivan, E., \& Owens, D.A. (1983). Catching a glimpse of quality costs today. Quality Progress, December, 21-24.

Superville, C.R., \& Gupta, S. (2001). Issues in modelling, monitoring and managing quality costs. The TQM Magazine, 13(6), 419-423. https://doi.org/10.1108/EUM0000000006178

Tye, L.H., Halim, H.A., \& Ramayah, T. (2011). An exploratory study on cost of quality implementation in Malaysia: The case of Penang manufacturing firms. Total Quality Management \& Business Excellence, 22(12), 1299-1315. https://doi.org/10.1080/14783363.2011.625191

Uyar, A. (2008). An exploratory study on quality costs in Turkish manufacturing companies. International Journal of Quality \& Reliability Management, 25(6), 604-620. https://doi.org/10.1108/02656710810881908

Williams, A.R.T., Van der Wiele, A., \& Dale, B.G. (1999). Quality costing: A management review. International Journal of Management Reviews, 1(4), 441-460.

Journal of Industrial Engineering and Management, 2019 (www.jiem.org)

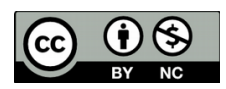

Article's contents are provided on an Attribution-Non Commercial 4.0 Creative commons International License. Readers are allowed to copy, distribute and communicate article's contents, provided the author's and Journal of Industrial Engineering and Management's names are included. It must not be used for commercial purposes. To see the complete license contents, please visit https://creativecommons.org/licenses/by-nc/4.0/. 